\title{
ECLETICA
}

www.scielo.br/eq

Volume 31, número 2, 2006

\section{Electrometric studies on formation of cerium vanadates as a function of $\mathrm{pH}$}

\author{
S.Prasad*, V. D. Leite ${ }^{b}$, R. A.C. Santana ${ }^{a}$ and E. A. Medeiros ${ }^{a}$ \\ ${ }^{a}$ Department of Chemical Engineering, Universidade Federal de Campina Grande, Cx. Postal 10108, \\ CEP 58109-970 Campina Grande, PB. \\ ${ }^{b}$ Department of Chemistry, Universidade Estadual da Paraíba,CEP 58104-485 Campina Grande, PB. \\ *Corrresponding author. E-mail: prasad@deq.ufcg.edu.br
}

\begin{abstract}
The precise nature of the reaction between nitric acid and sodium ortho-vanadate solutions has been studied by means of electrometric techniques involving potentiometric and conductometric titrations. The well defined inflections and breaks in the titration curves confirm the existence of the anions, pyro- $\mathrm{V}_{2} \mathrm{O}_{7}{ }^{4-}$, meta $-\mathrm{VO}_{3}{ }^{-}$and poly $-\mathrm{H}_{2} \mathrm{~V}_{10} \mathrm{O}_{28}{ }^{4-}$ corresponding to the ratios of $\mathrm{VO}_{4}{ }^{3-}: \mathrm{H}^{+}$as $1: 1$, 1:2 and 1:2.6 in the neighborhood of $\mathrm{pH} 10.5,7.4$ and 3.6, respectively. The interaction of cerium(III) nitrate with sodium vanadate solutions, at specific $\mathrm{pH}$ levels 12.4, 10.5, 7.4 and 3.6 was also studied by potentiometric and conductometric titrations between the reactants. The end-points obtained from the sharp inflections in the titration curves provide definite evidence for the formation and precipitation of cerium ortho- $\mathrm{Ce}_{2} \mathrm{O}_{3} \cdot \mathrm{V}_{2} \mathrm{O}_{5}$, pyro- $2 \mathrm{Ce}_{2} \mathrm{O}_{3} \cdot 3 \mathrm{~V}_{2} \mathrm{O}_{5}$ and meta- $\mathrm{Ce}_{2} \mathrm{O}_{3} \cdot 3 \mathrm{~V}_{2} \mathrm{O}_{5}$ vanadates in the neighborhood of $\mathrm{pH} 7.4,6.2$ and 4.8, respectively. Analytical investigations on the precipitates formed confirm the results of the electrometric study.
\end{abstract}

Keywords: vanadates; cerium vanadates; electrometry.

\section{Introduction}

The chemistry of vanadium is very prominent in both biological and industrial systems [1]. Besides this, a new interest in the chemistry of vanadium has developed during the last decades $[1,2]$. This has arisen in part from antiviral, including antiAIDS activity of vanadates and their interaction with biological molecules like proteins $[3,4]$. Vanadium also exhibits catalytic properties in an extensive variety of chemical reactions. These include the use of vanadium oxide as catalyst in the following: sulfur dioxide to the trioxide, the sulfonation of aromatic hydrocarbons or of pyridine, the reduction of olefines; the oxidation of hydroiodic acid by hydrogen peroxide, of sugar by nitric acid, of alcohol by air, of stannous salts by nitric acid, of cyclic organic compounds by hydrogen peroxide, of naphthalene by air, and the reduction of aromatic hydrocarbons by hydrogen [5]. A number of recent studies have shown that vanadium oxide catalyst is very promising in oxidative dehydrogenation of alkanes but its activity and selectivity depends on the manner in which the catalyst is pretreated [610]. The structure of the vanadia is a very important factor $[8,10]$. Khodakov et al [11] have recently determined that the oxidative dehydrogenation rates of propane increase as the size of poly-vanadate domain increases. Efforts aimed at relating the structures of the vanadium species to its catalytic activity and selectivity suggest that the catalytic performance depend on the type of structure, bond 
length and distance between active and selective sites [2,12-15].

In highly alkaline solution, $\mathrm{pH}>14$, vana$\operatorname{dium}(\mathrm{V})$ exists as a tetrahedral $\mathrm{VO}_{4}{ }^{3-}$ anion [16]. On acidification the aqueous solutions turn from colorless to orange-yellow polymeric species. A survey of literature suggests the occurrence of a series of alkali metal vanadates having the ratio of $\mathrm{Na}_{2} \mathrm{O}: \mathrm{V}_{2} \mathrm{O}_{5}$ as 3:1, 2:1, 1:1, 1:2, 1:2.5, 1:3, 2:3, etc. in solution under different conditions $[5,17]$. The existence of so many polymeric species seems to be doubtful; moreover, there is a great variance in the results published by earlier workers which allows no satisfactory interpretation of the mechanism of the condensation process. A further verification of the vanadate system seems very desirable with a view to rationalizing the conflicting details of the previous workers by employing electrometric techniques, which have provided more conclusive evidences on such systems [18-20]. The knowledge on the formation of different species under different conditions will help in the explanation of the catalytic performance of vanadium and may be a key to understanding the catalytic mechanism. In an earlier publication the results of $\mathrm{pH}$ change by $\mathrm{HCl}$ on solution of $\mathrm{Na}_{3} \mathrm{VO}_{4}$, and composition of nickel vanadates have been reported [21]. The results obtained on $\mathrm{pH}$ change of $\mathrm{Na}_{3} \mathrm{VO}_{4}$ by $\mathrm{HNO}_{3}$, and on formation of different vanadates of cerium(III) are presented here.

\section{Experimental}

$\mathrm{V}_{2} \mathrm{O}_{5}, \mathrm{NaOH}, \mathrm{Ce}\left(\mathrm{NO}_{3}\right)_{3}, \mathrm{HNO}_{3}$ and ethanol of extra-pure grade were used and their solutions were prepared with deionized distilled water. The solution of sodium ortho-vanadate $\mathrm{Na}_{3} \mathrm{VO}_{4}$ was prepared by digesting one mole of $\mathrm{V}_{2} \mathrm{O}_{5}$ in boiling solution of $\mathrm{NaOH}$ containing six moles of it.

$\mathrm{pH}$ measurements were carried out on Metrohm Herisau pH-meter using Scott Gerate glass combination electrode. Conductance values were recorded by employing a Metrohm conductometer. A series of $\mathrm{pH}$ and conductometric titrations was carried out between sodium ortho-vanadate in concentrations $\geq 10^{-4} \mathrm{~mol} \mathrm{l}^{-1}$ and nitric acid using same concentration of the reactants in each technique. All observations were taken at the state of chemical equilibrium. For attaining the equilibrium state the titrations were performed by heating the solution after each addition of titrant and cooling to $25^{\circ} \mathrm{C}$ before taking observations. All care was taken for maintaining concentration of the solution contents unaltered during the heating operation. The achievement of constant values of $\mathrm{pH}$ and conductance required about 30 seconds boiling after each addition of the titrant for the formation of pyro-vanadate, whereas the time needed for attaining the state of chemical equilibrium for the formation of meta- and poly-vanadate was 1 minute and 2.5 minutes, respectively. The curves were plotted between $\mathrm{pH}$ and corrected conductance versus volume of acid used.

\section{Cerium(III) vanadates}

The formation of cerium vanadates was investigated by the action of cerium(III) nitrate with different vanadate anions at specific $\mathrm{pH}$ levels 12.4, 10.5, 7.4 and 3.6 using different concentrations of the reactants. For this purpose, the variations of $\mathrm{pH}$ of $\mathrm{Na}_{3} \mathrm{VO}_{4}$ solutions were obtained by progressive additions of determined quantities of nitric acid. A series of $\mathrm{pH}$ and conductometric titrations was performed by direct and reverse methods, i.e. when cerium nitrate solution from the microburette was added to sodium vanadate solution and vice-versa. 25 $\mathrm{mL}$ of ethanolic solution $(20 \%)$ was taken in the cell, which was thermostated at $25 \pm 0.1^{\circ} \mathrm{C}$.

The precipitates obtained at the end-points of titrations between cerium nitrate and sodium vanadates were also analyzed to substantiate the electrometric results. The different cerium vanadates were prepared by mixing stoichiometric amounts of cerium nitrate solution with the respective sodium vanadate solutions. The precipitates obtained were washed several times with $20 \%$ ethanolic solution and dried in a vacuum desiccator for $40 \mathrm{~h}$. A known amount (ca $2 \mathrm{~g}$ ) of each of the above precipitates was dissolved in a minimum quantity of nitric acid and then analyzed quantitatively for cerium by ferrous ammonium sulfate [22a] and vanadium as silver vanadate [22b]. From the proportions of cerium and vanadium in the compounds thus obtained their composition was established. 


\section{Results and discussion}

In an earlier publication [21] Prasad et al. have shown that the addition of $\mathrm{HCl}$ to $\mathrm{Na}_{3} \mathrm{VO}_{4}$ solutions at room temperature causes the formation of various poly-anions of uncertain compositions, but when the solutions were heated after each addition of titrant the three different vanadates viz. Pyro $\left(\mathrm{Na}_{4} \mathrm{~V}_{2} \mathrm{O}_{7}\right)$, meta $\left(\mathrm{NaVO}_{3}\right)$ and poly $\left(\mathrm{Na}_{4} \mathrm{H}_{2} \mathrm{~V}_{10} \mathrm{O}_{28}\right)$ are formed in the neighborhood of $\mathrm{pH} 10.5,7.4$ and 3.6, respectively. In the present study related to the formation of different cerium(III) vanadates as a function of $\mathrm{pH}$, by the interaction of cerium(III) nitrate with alkali vanadates at specific $\mathrm{pH}$ levels, the use of $\mathrm{HNO}_{3}$ for $\mathrm{pH}$ variation was considered more appropriate because it involves the same cation (nitrate) as present in cerium nitrate. Hence it was considered of interest to ascertain whether similar alkali vanadate species are formed by the action of $\mathrm{HNO}_{3}$ with $\mathrm{Na}_{3} \mathrm{VO}_{4}$ solutions. A series of glass electrode and conductometric titrations of $\mathrm{Na}_{3} \mathrm{VO}_{4}$ solution with $\mathrm{HNO}_{3}$ were therefore performed. A typical titration curve between $\mathrm{pH}$ observed and volume of the acid added is demonstrated in Fig 1 (curve 1). The three inflections in the titration curve at the molar ratios of $\mathrm{H}^{+}: \mathrm{VO}_{4}{ }^{3-}$ as 1,2 and 2.6 corresponding to the stoichiometry for the formation of pyro- $\mathrm{V}_{2} \mathrm{O}_{7}$, meta- $\mathrm{VO}_{3}^{-}$and poly$\mathrm{H}_{2} \mathrm{~V}_{10} \mathrm{O}_{28}{ }^{4-}$ anions confirm the formation of the same three vanadate species as obtained by our previous study with $\mathrm{HCl}$ [21]. The conductometric titrations between the acid and $\mathrm{Na}_{3} \mathrm{VO}_{4}$ also confirm the formation of the same species (Fig. 1, curve 2). The stiochiometry obtained by this electrometric study did not correspond to confirm the existence of $\mathrm{V}_{6} \mathrm{O}_{16}{ }^{2-}$ as reported by Sen Gupta [23] and Russel and Salmon [24], and of $\mathrm{V}_{3} \mathrm{O}_{8}{ }^{-}, \mathrm{V}_{5} \mathrm{O}_{14}{ }^{3-}, \mathrm{V}_{10} \mathrm{O}_{28}{ }^{6-}$ and $\mathrm{HV}_{10} \mathrm{O}_{28}{ }^{5-}$ as reported by Bystrom and Evans [25] and Naumann and Hallada [26].

The stepwise condensation of orthovanadate to poly-vanadate can be represented by the following set of equations:

$$
\begin{aligned}
& 2 \mathrm{VO}_{4}^{3-}+2 \mathrm{H}^{+}=\mathrm{V}_{2} \mathrm{O}_{7}^{4-}+\mathrm{H}_{2} \mathrm{O} \\
& \mathrm{V}_{2} \mathrm{O}_{7}^{4-}+2 \mathrm{H}^{+}=2 \mathrm{VO}_{3}{ }^{-}+\mathrm{H}_{2} \mathrm{O} \\
& 0 \mathrm{VO}_{3}{ }^{-}+6 \mathrm{H}^{+}=\mathrm{H}_{2} \mathrm{~V}_{10} \mathrm{O}_{28}{ }^{4-}+2 \mathrm{H}_{2} \mathrm{O}
\end{aligned}
$$

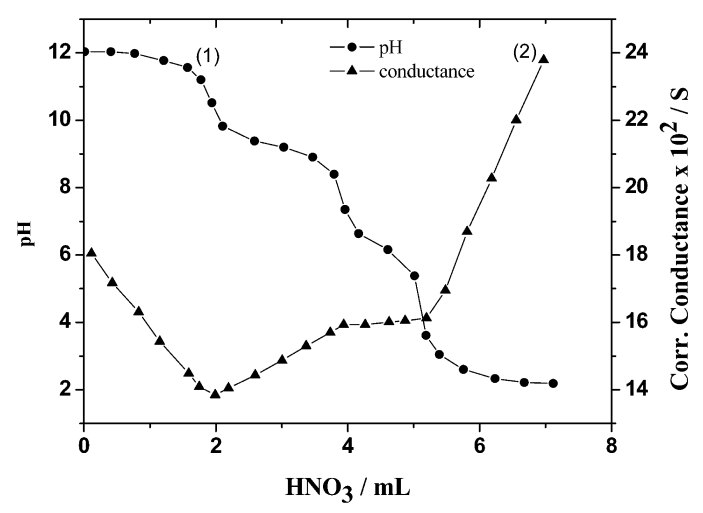

Figure 1. $\mathrm{pH}$ (1) and conductometric (2) titrations. $25 \mathrm{~mL}$ of $\mathrm{M} / 50 \mathrm{Na}_{3} \mathrm{VO}_{4}$ titrated with $\mathrm{M} / 5$ $\mathrm{HNO}_{3}$.

The above studies show that the addition of acid to sodium ortho-vanadate under suitable conditions causes the formation of three different sodium vanadates containing the anions Pyro$\mathrm{V}_{2} \mathrm{O}_{7}{ }^{4-}$, meta- $\mathrm{VO}_{3}{ }^{-}$and poly $-\mathrm{H}_{2} \mathrm{~V}_{10} \mathrm{O}_{28}{ }^{4-}$. Therefore it was considered of interest to ascertain whether similar salts of heavy metals may be precipitated as a result of double decomposition. The reactions of $\mathrm{Ce}(\mathrm{III})$ with alkali vanadates have therefore been studied by means of potentiometric and conductometric titrations. A solution of sodium ortho-vanadate was prepared by digesting one mole of $\mathrm{V}_{2} \mathrm{O}_{5}$ in boiling solution of $\mathrm{NaOH}$ containing six moles of it. The solutions of sodium pyro-, meta- and poly-vanadates were prepared by adding one, two and 2.6 moles of $\mathrm{HNO}_{3}$ to one mole of $\mathrm{Na}_{3} \mathrm{VO}_{4}$ at $100^{\circ} \mathrm{C}$.

$$
\begin{aligned}
& \begin{array}{l}
6 \mathrm{NaOH}+\mathrm{V}_{2} \mathrm{O}_{5}= \\
2 \mathrm{NaO}_{3} \mathrm{VO}_{4}+3 \mathrm{H}_{2} \mathrm{O}
\end{array} \\
& 2 \mathrm{Na}_{3} \mathrm{VO}_{4}=\mathrm{Na}_{4} \mathrm{~V}_{2} \mathrm{O}_{7}+2 \mathrm{NaNO}_{3}+\underset{\mathrm{H}_{2} \mathrm{O}}{(4)} \\
& \begin{array}{l}
26 \mathrm{HNO}_{3}+\mathrm{Na}_{3} \mathrm{VO}_{4}=\mathrm{NaVO}_{3}+2 \mathrm{NaNO}_{3}+\underset{\mathrm{H}_{2} \mathrm{O}}{(6)} \\
26 \mathrm{NaNO}_{3}+10 \mathrm{Na}_{3} \mathrm{VO}_{4}=
\end{array} \mathrm{Na}_{4} \mathrm{H}_{2} \mathrm{~V}_{10} \mathrm{O}_{28}+ \\
&
\end{aligned}
$$

\section{Formation of cerium(III) vanadates}

A series of direct and reverse electrometric titrations between the solutions of cerium(III) nitrate $(\mathrm{pH} 3.5)$ and different sodium vanadates at specific $\mathrm{pH}$ levels $12.4,10.5,7.4$ and 3.6 were 
Table 1. Summary of results of electrometric study on formation of cerium vanadates.

Volume of titre solution taken in the cell $=25 \mathrm{ml}$

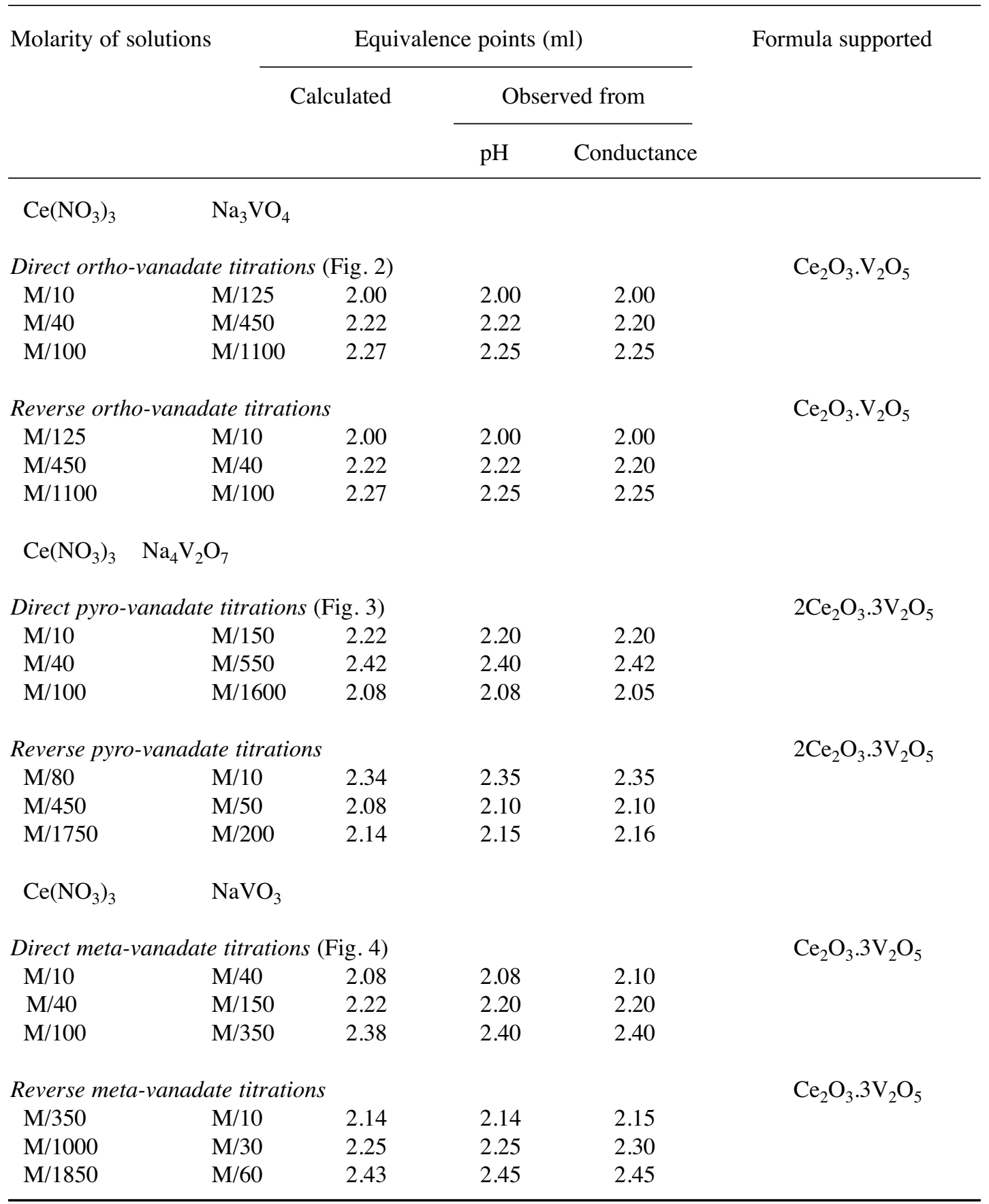

realized and the results obtained from the stoi- Only three Figures illustrating the formation of chiometric end-points are summarized in Table 1. cerium ortho-vanadate (Fig. 2) ), pyro-vanadate 


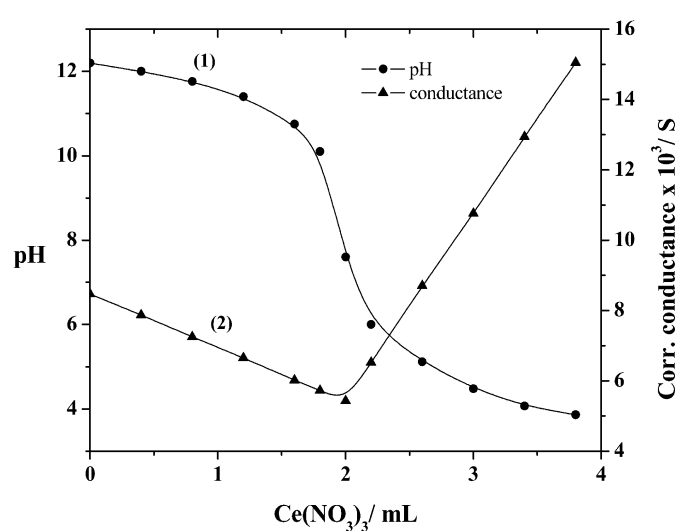

Figure 2. Cerium ortho-vanadate titrations. 25 $\mathrm{mL}$ of $\mathrm{M} / 125 \quad \mathrm{Na}_{3} \mathrm{VO}_{4}$ titrated with $\mathrm{M} / 10$ $\mathrm{Ce}\left(\mathrm{NO}_{3}\right)_{3}$.

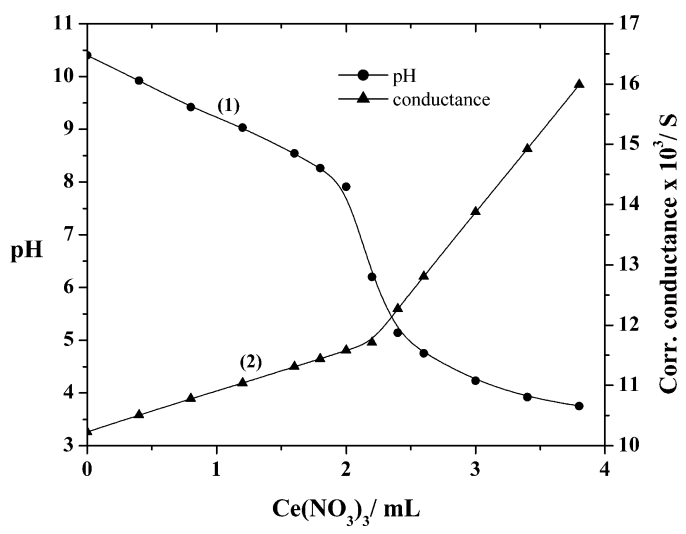

Figure 3. Cerium pyro-vanadate titrations. 25 $\mathrm{mL}$ of $\mathrm{M} / 150 \quad \mathrm{Na}_{4} \mathrm{~V}_{2} \mathrm{O}_{7}$ titrated with $\mathrm{M} / 10$ $\mathrm{Ce}\left(\mathrm{NO}_{3}\right)_{3}$.

(Fig. 3) and meta-vanadate (Fig. 4) by direct titrations have been given for the sake of brevity. The precipitates obtained at the end-points of the electrometric titrations between cerium nitrate and sodium vanadates were also analyzed to substantiate the electrometric results. The analytical results are presented in Table 2 .

\section{Cerium ortho-vanadate}

Using different concentrations of cerium(III) nitrate $(\mathrm{pH} 3.5)$ and $\mathrm{Na}_{3} \mathrm{VO}_{4}(\mathrm{pH}$ 12.4) a

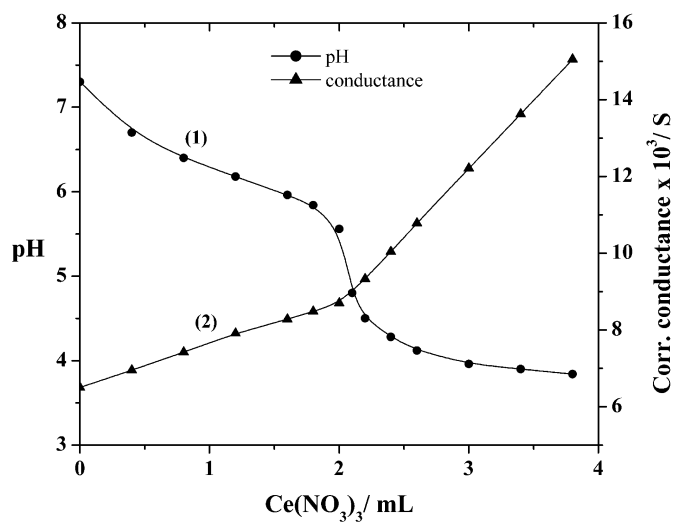

Figure 4. Cerium meta-vanadate titrations. 25 $\mathrm{mL}$ of $\mathrm{M} / 40 \quad \mathrm{NaVO}_{3}$ titrated with $\mathrm{M} / 10$ $\mathrm{Ce}\left(\mathrm{NO}_{3}\right)_{3}$.

series of $\mathrm{pH}$ titrations was carried out. Fig. 2 (curve 1) shows the changes occurring in $\mathrm{H}^{+}$ion concentration when the solution of $\mathrm{Na}_{3} \mathrm{VO}_{4}$ was titrated with cerium nitrate solution. It may be noted that the first addition of acidic cerium nitrate solution to the alkaline vanadate results in gradual decrease in $\mathrm{pH}$ to about 11.0. Further addition of the titrant brings about steep fall in $\mathrm{pH}$ value at a point where the molar ratio of $\mathrm{Ce}^{3+}: \mathrm{VO}_{4}{ }^{3-}$ is $1: 1$ (see Table 1 ), corresponding to the stoichiometry for the precipitation of cerium ortho-vanadate $\mathrm{Ce}_{2} \mathrm{O}_{3} \cdot \mathrm{V}_{2} \mathrm{O}_{5}$ in the vicinity of $\mathrm{pH}$ 7.4. The reaction can be represented as follows:

$2 \mathrm{Ce}\left(\mathrm{NO}_{3}\right)_{3}+2 \mathrm{Na}_{3} \mathrm{VO}_{4}=\mathrm{Ce}_{2} \mathrm{O}_{3} \cdot \mathrm{V}_{2} \mathrm{O}_{5}+6 \mathrm{NaNO}_{3}$

In the case of conductometric titrations of the solution of $\mathrm{Na}_{3} \mathrm{VO}_{4}$ with cerium nitrate (Fig. 2 , curve 2) the conductance value decreases gradually in the beginning of the titration (due to removal of the $\mathrm{VO}_{4}{ }^{3-}$ ions in the form of a precipitate), but after completion of the reaction, conductance starts rising with the increase in ionic concentration at the ratio $\mathrm{Ce}^{3+}: \mathrm{VO}_{4}{ }^{3-}$ as $1: 1$, which coincides with the stoichiometry indicated by the $\mathrm{pH}$ study.

\section{Cerium pyro-vanadate}

Fig. 3 (curve 1) illustrates the changes 
Table 2. Summary of analytical results of the precipitates of cerium vanadates

\begin{tabular}{|c|c|c|c|}
\hline \multirow{2}{*}{$\begin{array}{l}\text { Proposed formula } \\
\text { of the compound }\end{array}$} & \multirow[t]{2}{*}{ Mode of analysis } & \multicolumn{2}{|c|}{ Analysis \%: Found (Calculated) } \\
\hline & & $\mathrm{Ce}$ & $\mathrm{V}$ \\
\hline \multicolumn{4}{|c|}{ Analysis of cerium ortho-vanadate precipitates } \\
\hline \multirow[t]{2}{*}{$\mathrm{Ce}_{2} \mathrm{O}_{3} \cdot \mathrm{V}_{2} \mathrm{O}_{5}$} & Directa & $54.89(54.94)$ & 20.01(19.97) \\
\hline & Reverse $^{b}$ & 54.97 & 19.94 \\
\hline \multicolumn{4}{|c|}{ Analysis of cerium pyro-vanadate precipitates } \\
\hline \multirow[t]{2}{*}{$2 \mathrm{Ce}_{2} \mathrm{O}_{3} \cdot 3 \mathrm{~V}_{2} \mathrm{O}_{5}$} & Direct & $46.58(46.62)$ & $25.45(25.43)$ \\
\hline & Reverse & 46.67 & 25.40 \\
\hline \multicolumn{4}{|c|}{ Analysis of cerium meta-vanadate precipitates } \\
\hline \multirow[t]{2}{*}{$\mathrm{Ce}_{2} \mathrm{O}_{3} \cdot 3 \mathrm{~V}_{2} \mathrm{O}_{5}$} & Direct & $32.02(32.07)$ & $35.04(34.98)$ \\
\hline & Reverse & 32.11 & 34.95 \\
\hline
\end{tabular}

a Cerium nitrate solution added to sodium ortho-vanadate solution.

bSodiun ortho-vanadate solution added to cerium nitrate solution.

occurring when cerium nitrate solution $(\mathrm{pH} 3.5)$ was added from the microburette to the solution of sodium pyro-vanadate ( $\mathrm{pH} 10.5)$. The titration curve shows a well-defined inflection at the equivalence point, where the molar ratio $\mathrm{Ce}^{3+}: \mathrm{V}_{2} \mathrm{O}_{7}{ }^{4-}$ is $4: 3$, corresponding to the stoichiometry for the formation of cerium pyrovanadate $2 \mathrm{Ce}_{2} \mathrm{O}_{3} \cdot 3 \mathrm{~V}_{2} \mathrm{O}_{5}$, in the neighborhood of $\mathrm{pH}$ 6.2. The reaction can be represented by the following equation:

$4 \mathrm{Ce}\left(\mathrm{NO}_{3}\right)_{3}+3 \mathrm{Na}_{4} \mathrm{~V}_{2} \mathrm{O}_{7}=\left(2 \mathrm{Ce}_{2} \mathrm{O}_{3} \cdot 3 \mathrm{~V}_{2} \mathrm{O}_{5}\right)+$ $12 \mathrm{NaNO}_{3}$

Employing similar concentrations of the reactants a series of conductometric titrations between the solution of cerium nitrate and sodium pyro-vanadate was carried out. Well-defined breaks in the titration curves (Fig. 3, curve 2) were obtained at 4:3 molar ratio of $\mathrm{Ce}^{3+}: \mathrm{V}_{2} \mathrm{O}_{7}{ }^{4-}$, which confirm the formation of the identical compound, cerium pyrovanadate $2 \mathrm{Ce}_{2} \mathrm{O}_{3} \cdot 3 \mathrm{~V}_{2} \mathrm{O}_{5}$. In these titrations, when cerium nitrate solution was added from the microburette to sodium pyro-vanadate solution in the titration cell, a gradual increase in conductance value was observed until the stoichiometric endpoint, after which the conductance increased sharply with the increase in ionic concentration.

\section{Cerium meta-vanadate}

Using different concentrations of cerium nitrate $(\mathrm{pH} \mathrm{3.5)}$ and sodium meta-vanadate $(\mathrm{pH}$ 7.4) a series of $\mathrm{pH}$ and conductometric titrations (Fig. 4) was carried out. The breaks and inflections in the titration curves at the stoichiometric end-point corresponding to the molar ratio $\mathrm{Ce}^{3+}: \mathrm{VO}_{3}{ }^{-}$as $1: 3$, suggest the formation of cerium meta-vanadate $\mathrm{Ce}_{2} \mathrm{O}_{3} \cdot 3 \mathrm{~V}_{2} \mathrm{O}_{5}$ in the neighborhood of $\mathrm{pH} 4.8$, according to the equation:

$2 \mathrm{Ce}\left(\mathrm{NO}_{3}\right)_{3}+6 \mathrm{NaVO}_{3}=\mathrm{Ce}_{2} \mathrm{O}_{3} \cdot 3 \mathrm{~V}_{2} \mathrm{O}_{5}+6 \mathrm{NaNO}_{3}$

Similar studies using the different sodium vanadate solutions as titrant (reverse titrations) was also realized (Table 1). The breaks and inflections in titration curves confirmed the results obtained by the direct titrations. As the curves were normal in shape and nature the figures of these titrations are not presented for the sake of brevity.

The reaction between cerium nitrate and sodium poly-vanadate $\mathrm{Na}_{4} \mathrm{H}_{2} \mathrm{~V}_{10} \mathrm{O}_{28}$ (pH 3.6) was also studied, but the curves did not exhibit any appreciable break or inflection at the stoichiometric end-point. This may be ascribed to too small difference in the $\mathrm{pH}$ values of the reactants for getting inflection in the potentiometric 
titrAtion curves and the presence of $\mathrm{NaNO}_{3}$ in appreciable amount in poly-vanadate solution (see Eqn. 7) for preventing occurrence of breaks in the conductometric titration curves.

The precipitates obtained at the end-points of the titrations of cerium nitrate with sodium vanadates were analyzed by classical methods. Cerium was determined volumetrically by ferrous ammonium sulfate and vanadium gravimetrically as silver vanadate, and oxygen was calculated from the difference in the percentage. From the proportions of cerium, vanadium and oxygen in the compounds thus obtained, their compositions were established, which were found to be the same as obtained by the electrometric study (Table 2 ).

It was noted that the presence of ethanol in cerium vanadate titrations slightly improves the end-points and gives better results as it decreases solubility of the precipitates formed and minimizes hydrolysis and adsorption. 20\% ethanolic medium was therefore employed for the entire course of the study. A thorough stirring in the vicinity of the end-point had a favorable effect.

As the structure of these compounds is not known these are represented as double oxides, the manner, which is usually adopted for such, compounds $[27,28]$.

\section{Conclusions}

The results of the electrometric investiga- tions on the system nitric acid and sodium orthovanadate, at the specific concentration level of $\geq$ $10^{-4} \mathrm{M}$, suggest the formation of para $-\mathrm{V}_{2} \mathrm{O}_{7}$, meta$\mathrm{VO}_{3}{ }^{-}$and poly- $\mathrm{H}_{2} \mathrm{~V}_{10} \mathrm{O}_{28}{ }^{4-}$ vanadate anions in the neighborhood of $\mathrm{pH} 10.5,7.4$ and 3.6, respectively. The results obtained by this study are similar to those obtained by using hydrochloric acid [21]. The electrometric and analytical investigations on the interaction of cerium(III) nitrate with sodium vanadate at specific $\mathrm{pH}$ levels $12.4,10.5$ and 7.4 provide cogent evidence for the formation and precipitation of cerium ortho- $\mathrm{Ce}_{2} \mathrm{O}_{3} \cdot \mathrm{V}_{2} \mathrm{O}_{5}$, pyro$2 \mathrm{Ce}_{2} \mathrm{O}_{3} \cdot 3 \mathrm{~V}_{2} \mathrm{O}_{5}$ and meta- $\mathrm{Ce}_{2} \mathrm{O}_{3} \cdot 3 \mathrm{~V}_{2} \mathrm{O}_{5}$ vanadates in the vicinity of $\mathrm{pH} 7.4,6.2$ and 4.8, respectively. The composition of heavy metal vanadates can thus be represented by the general formula $n \mathrm{M}_{2} \mathrm{O}_{3} .3 \mathrm{~V}_{2} \mathrm{O}_{5}$ for a trivalent metal and the proportion of the metal oxide in the vanadate obtained decreases with the $\mathrm{pH}$ of the medium. Therefore by controlling the $\mathrm{pH}$ of the medium one can control the composition of the vanadate.

\section{Acknowledgement}

The authors wish to express their sincere thanks to the $\mathrm{CNPq}$, Brasília, for financial assistance.

Recebido em: 01/02/2006

Aceito em: 05/05/2006 
S. Prasad, V. D. Leite, R. A.C. Santana e E. A. Medeiros. Formação de vanadatos de cério(III) em função do $\mathrm{pH}$.

Resumo: A natureza precisa da reação entre soluções de ácido nítrico e de ortho-vanadato de sódio foi estudada por técnicas electrométricas envolvendo titulações potenciométricas e condutométricas. As inflexões e degraus bem definidas nas curvas de titulações confirmaram a existencia de anions, piro$\mathrm{V}_{2} \mathrm{O}_{7}{ }^{4-}$, meta- $\mathrm{VO}_{3}{ }^{-}$e poli $-\mathrm{H}_{2} \mathrm{~V}_{10} \mathrm{O}_{28}{ }^{4-}$ correspondendo as razões de $\mathrm{VO}_{4}{ }^{3-}: \mathrm{H}^{+}$como 1:1, 1:2 e 1:2,6 na vizinhança do $\mathrm{pH} 10,5 ; 7,4$ e 3,6, respectivamente. A interação entre soluções de nitrato de cério(III) e vanadato de sódio a específicos níveis de pH 12,4; 10,5; 7,4 e 3,6 também foi estudada por titulações potenciométricas e condutométricas entre os reagentes. Os pontos finais obtidos a partir de inflexções nítidas nas curvas de titulações forceram evidências incontestáveis sobre a formação e precipitação de vanadatos orto- $\mathrm{Ce}_{2} \mathrm{O}_{3} \cdot \mathrm{V}_{2} \mathrm{O}_{5}$, piro- $2 \mathrm{Ce}_{2} \mathrm{O}_{3} \cdot 3 \mathrm{~V}_{2} \mathrm{O}_{5}$ e meta- $\mathrm{Ce}_{2} \mathrm{O}_{3} \cdot 3 \mathrm{~V}_{2} \mathrm{O}_{5}$ de cério nas proximidades dos valores de $\mathrm{pH} 7,4 ; 6,2$ e 4,8, respectivamente. Investigações analíticas sobre os precipitados formados confirmam os resultados do estudo eletrométrico.

Palavras-chave: vanadatos; vanadatos de cério; eletrometria.

\section{References}

[1] D. Hou, New Chemistry of Polyvanadates in Non-aqueous and Aqueous Media, Emory Univ. Atlanta, GA, Aval. Univ. Microfilms Int., Order No. DA9505696, 1994, p. 229.

[2] V. F. Odyakov, K. J. Matveev, Izobreteniya, 47 (1993) 172.

[3] D. C. Crans, Comments Inorg. Chem. v. 16(1,2) (1994) 1, 35.

[4] R. Miesel, German Patent, DE 4,334,642; 27 April 1995.

[5] R. J. H. Clark, in: A. F. Trotman-Dickenson (Exec. Ed.), Comprehensive Inorganic Chemistry, Vol. 3, Pergamon Press, Oxford, 1975, p. 513, chap. 34.

[6] S. Albonetti, F. Cavani, F. Trifiro, Catal. Rev.-Sci. Eng. 38 (1996) 413.

[7] T. Blasco, J. M. López Nieto, Appl. Catal. 157 (1997) 117.

[8] G. Centi, Appl. Catal. A 147 (1996) 267.

[9] H. H. Kung, Adv. Catal. 133 (1995) 219.

[10] I. E. Wachs, B. M. Weckhuysen, Appl. Catal. A, 157 (1997) 67.

[11] A. Khodakov, J. Yang, S. Su, E. Iglesia, A. T. Bell, J. Catal. 177 (1998) 343.

[12] G. Centi, S. Perathoner, F. Trifiro, A. Aboukais, C. F. Aissi, M. Guelton, J. Phys. Chem. 96 (1992) 2617.

[13] A. Corma, J. M. López Nieto, N. Paredez, J. Catal. 144 (1993) 425.
[14] P. Michalakos, M. C. Kung, I. Jahan, H. H. Kung, J. Catal. 140 (1993) 226.

[15] L. Owens, H. H. Kung, J. Catal. 148 (1994) 587.

[16] D. L. Kepert, in: A. F. Trotman-Dickenson, (Exec. Ed.), Comprehensive Inorganic Chemistry, Vol. 4, Pergamon Press, Oxford, 1973, p. 625 Chap. 51.

[17] M. T. Pope, B. W. DAle, Quart. Rev. 22 (1968) 527.

[18] S. Prasad, Can. J. Chem 59 (1981) 563.

[19] S. Prasad, Bull. Electrochem. 6 (1990) 163.

[20] S. Prasad, Quím. Nova, 17 (1994) 31.

[21] S. Prasad, V. D. Leite, R. A. C. Santana, E. S. Moura, A. F. A. Neto, A. G. Souza, J. Braz. Chem. Soc. 15 (2004) 427.

[22] A. I. Vogel, A Textbook of Quantitative Inorganic Analysis, 3rd Edition, Longmans, London, 1968, p. (a) 325, (b) 538.

[23] A. K. Sen Gupta, Z. Anorg. Allgem. Chem 304 (1960) 328. [24] R. U. Russel, J. E. Salmon, J. Chem. Soc. (A) (1958) 4708. [25] A. M. Bystrom, H. T. Evans, Acta Chem. Scand. 13 (1959) 377.

[26] A. W. Naumann, C. J. Hallada, Inorg. Chem. 5 (1966) 1808. [27] G. Brauer, (Ed.), Handbook of Preparative Inorganic Chemistry, Vol. 2, Academic Press, New York, $2^{\text {nd }}$ edn., 1996, p. 1705.

[28] A. Standen, (Exec. Ed.), Kirk-Othmer Encyclopedia of Chemical Technology, Vol. 13, Interscience Publishers, New York, $2^{\text {nd }}$ edn.,1967, p. 782. 